\title{
PENGARUH PEMANFAATAN LINGKUNGAN SEBAGAI SUMBER BELAJAR IPS TERHADAP PEMAHAMAN KONSEP DAN PENGEMBANGAN SIKAP KEPEDULIAN SOSIAL SISWA SEKOLAH DASAR
}

\author{
(Studi Eksperimen Pada Siswa Kelas III SD Sukahaji Cimekar Kec. Cileunyi)
}

\author{
Uus Yusmantara S.
}

\begin{abstract}
ABSTRAK
Pembelajaran merupakan bagian integral dalam proses pendidikan, karena itu peran guru menempati posisi sentral dalam melaksanakan pembelajaran secara optimal, sehingga motivasi, aktivitas, dan kreativitas siswa dapat berkembang dalam suasana belajar yang kondusif. Salah satu bentuk implementasi pengelolaan pembelajaran yang diduga mampu mengakomodir kondisi belajar tersebut, antara lain melalui pemanfaatan lingkungan sebagai sumber belajar IPS. Tujuan penelitian ini adalah untuk mengetahui "besarnya pengaruh pemanfaatan lingkungan sebagai sumber belajar IPS bagi pemahaman konsep dan pengembangan sikap kepedulian sosial siswa terhadap lingkungannya”.

Metode yang digunakan dalam penelitian ini menerapkan pendekatan eksperimen semu (quasi experiment) dengan desain kelompok acak pretest-posttest dengan kelompok kontrol (Control Group Pretest-Posttest Design), dengan melibatkan sampel 100 orang siswa kelas tiga SD Sukahaji, Cimekar Kecamatan Cileunyi, yang terbagi atas dua kelompok/kelas, yaitu 50 orang siswa sebagai kelompok eksperimen dan 50 orang siswa lainnya sebagai kelompok kontrol yang ditetapkan secara acak. Alat pengumpul data dalam penelitian ini menggunakan alat tes obyektif pilihan ganda dengan empat option pilihan jawaban, dengan tujuan untuk mengukur tingkat pemahaman konsep, Angket skala Likert digunakan untuk mengetahui sikap kepedulian sosial siswa terhadap lingkungannya, Panduan observasi serta wawancara, yaitu untuk mengetahui implementasi perilaku konkret atas sikap yang terungkap pada pernyataan jawaban angket. Data yang berhasil dikumpulkan, kemudian diolah dan dianalisis melalui program Anates, SPSS 13 dan excel 2003.

Hasil penelitian menunjukkan bahwa: pemanfaatan lingkungan sebagai sumber belajar IPS, ternyata berpengaruh positif terhadap pemahaman konsep dan pengembangan sikap kepedulian sosial siswa kelas tiga Sekolah Dasar, sehingga diketahui perbedaan tingkat pemahaman konsep dan pengembangan sikap kepedulian sosial antara kelompok eksperimen dengan kelompok kontrol. Dengan demikian, penerapan model pendekatan pemanfaatan lingkungan sebagai sumber belajar dapat dijadikan salah satu alternatif pilihan guru dalam membelajarkan materi IPS di Sekolah Dasar khususnya dan proses pembelajaran pada umumnya.
\end{abstract}

\section{Kata Kunci : Lingkungan sebagai Sumber Belajar, Pemahaman Konsep, Sikap Kepedulian Sosial}




\section{A. PENDAHULUAN}

Kurikulum menempati posisi sentral dalam setiap upaya pembaharuan pendidikan. Artinya bahwa setiap kegiatan pendidikan ditandai dengan terjadinya proses interaksi akademik secara simultan antara pendidik, peserta didik, materi, metode, media dan sumber belajar. Posisi sentral kurikulum tersebut merupakan langkah strategis dalam upaya mencerdaskan bangsa dan meningkatkan kualitas hidup manusia. Kurikulum tingkat satuan pendidikan (KTSP 2006) merupakan salah satu wujud upaya pembaharuan pendidikan, yang di dalamnya mengisyaratkan tuntutan perubahan paradigma sistem pendidikan dan pembelajaran. Proses interaksi akademik dalam paradigma baru menggeser proses pembelajaran yang semula berpusat pada aktivitas guru (teacher centered) menjadi model pembelajaran yang lebih berpusat pada aktivitas siswa (student centered atau pupil centered), orientasi materi yang semula sangat tergantung secara tekstual menjadi kontekstual dan terpadu (integrated), pendekatan pembelajaran yang semula bersifat ekspositorik menjadi partisipatorik, dan sebagainya.

Melalui perubahan paradigma pendidikan, khususnya pada pembelajaran materi kajian IPS di Sekolah Dasar, diharapkan akan mampu menghapus image masyarakat, siswa dan kalangan akademisi bahwa mata pelajaran IPS termasuk mata pelajaran yang membosankan dan cenderung kurang disenangi dan diminati oleh sebagian besar siswa di Sekolah Dasar. Sebagaimana dikemukakan Al Muchtar (2004:5), bahwa: “IPS merupakan bidang studi yang menjemukan dan kurang menantang minat belajar siswa, bahkan lebih dari itu IPS dipandang sebagai mata pelajaran kelas dua oleh siswa maupun oleh orang tua siswa”.

Rendahnya motivasi siswa dalam mengikuti pembelajaran IPS, diduga bersumber dari tudingan terhadap penerapan model pembelajaran itu sendiri yang tidak mampu memenuhi tuntutan perkembangan dan kebutuhan belajar siswa, sebagai akibat karena setiap kali guru membahas materi kajian IPS tidak menerapkan variasi metode dan penggunaan berbagai media dan sumber belajar yang terdapat di sekitar lingkungan keseharian hidup siswa, sehingga pembelajaran lebih didominasi oleh penerapan metode ceramah (pendekatan ekspositorik) dan cenderung pembelajaran bersifat monoton. Hal ini sejalan dengan pandangan yang 
dikemukakan Somantri (2001:54), bahwa: “salah satu kelemahan dalam pembelajaran IPS adalah menekankan pada strategi ceramah dan ekspositori atau transfer of knowledge yang menjadikan guru sebagai pusat kegiatan belajar mengajar”. Sehingga secara substansial seakan-akan proses pembelajaran lebih didominasi guru tanpa memberikan akses keterlibatan siswa secara aktif, kreatif dan inovatif dalam proses pemebelajaran. Padahal secara hakiki, perkembangan intelektual siswa pada usia Sekolah Dasar berada pada fase operasional konkret ( concrete operations ), sebagaimana dikemukakan Piaget (1961), bahwa: “perkembangan anak pada fase concrete operations ditandai dengan kemampuan mengelompokkan (mengklasifikasi), menyusun atau mengasosiasikan (menghubungkan atau menghitung) angka dan bilangan, dan sikap pemecahan masalah (problem solving) yang sederhana”. Dengan kata lain bahwa kemampuan intelektual siswa pada fase tersebut masih terbatas pada pemahaman sejumlah konsep konkret, yang secara factual dapat dilihat dan dialami dalam lingkungan hidup siswa.

Berkenaan dengan karakteristik kemampuan belajar siswa pada fase perkembangan pada usia sekolah (6-12) tahun, materi IPS di Sekolah Dasar menurut Permendiknas No. 22 tahun 2006 tentang standar isi disesuaikan dan dirancang untuk mengembangkan pengetahuan, pemahaman, dan kemampuan analisis terhadap kondisi sosial masyarakat dalam memasuki kehidupan bermasyarakat yang dinamis, yang di dalamnya mengkaji seperangkat peristiwa fakta, konsep dan generalisasi yang berkaitan dengan isu sosial yang terjadi dalam.kehidupan bermasyarakat.

Salah satu permasalahan yang sangat mendasar dalam pembelajaran IPS di Sekolah Dasar adalah rendahnya daya serap siswa terhadap pemahaman materi pembelajaran yang disajikan guru. Tentunya banyak hal yang mempengaruhinya, seperti karakteristik materi, tingkat ketersediaan dan keterbacaan buku teks, metode dan model pendekatan pembelajaran yang diterapkan guru. Namun kenyataan di lapangan, dari berbagai penyebab tersebut ternyata yang paling urgen dan esensial keberadaannya adalah masih banyaknya guru yang menerapkan model pembelajaran konvensional dalam membelajarkan materi IPS di Sekolah Dasar yang ternyata belum mampu menyentuh esensi dasar kebutuhan belajar dan kebutuhan 
perkembangan siswa. Sementara itu lingkup materi IPS mengkaji tentang manusia dan lingkungannya dengan segala fenomena yang terdapat di dalamnya. Sebagaimana dikemukakan Sumaatmadja, (1980:16), bahwa Ilmu Pengetahuan Sosial adalah bidang-bidang yang digali dari kehidupan praktis sehari-hari di masyarakat. Oleh karena itu, pengajaran IPS yang melupakan masyarakat sebagai sumber dan obyeknya, merupakan suatu bidang pengetahuan yang tidak berpijak kepada kenyataan. IPS yang tidak bersumber kepada kenyataan tidak mungkin mencapai sasaran dan tujuannya, dan tidak akan memenuhi tuntutan kemasyarakatan. Hal senada dikemukakan pula oleh Poedjiadi (2005:79), bahwa: "Dengan menggunakan lingkungan sebagai sumber belajar, diharapkan siswa akan memiliki kepedulian terhadap lingkungannya, dan berawal dari pemahaman konsep dan kepedulian itu, siswa dapat mencari solusi, mengambil keputusan, dan melakukan tindakan nyata ketika menghadapi masalah dalam lingkungan mereka sendiri”.

Bertolak dari pandangan tersebut, maka dinilai perlu untuk sesegera mungkin memperbaharui paradigma pembelajaran IPS yang mampu menyentuh kebutuhan esesnsi belajar siswa, sehingga belajar IPS menjadi lebih bermakna bagi kehidupan siswa dalam lingkungan masyarakatnya. Untuk memfasilitasi hal tersebut, maka guru hendaknya senantiasa berupaya untuk mendekatkan materi kajian IPS dengan lingkungan keseharian hidup siswa. Karena lingkungan, baik lingkungan fisik, sosial, maupun lingkungan budaya merupakan media dan sumber belajar yang kaya dengan berbagai konsep, dan nilai serta moral dan norma yang dapat mengembangkan sikap kepedulian sosial siswa dan mengimplementasikannya dalam kehidupan bermasyarakat.

Penerapan model pendekatan pemanfaatan lingkungan sebagai sumber belajar IPS, diharapkan menjadi salah satu alternatif pilihan guru dalam membelajarkan materi kajian IPS di Sekolah Dasar. Karena pemanfaatan lingkungan sebagai media dan sumber belajar, sangat relevan dengan karakteristik fase perkembangan siswa kelas tiga Sekolah Dasar yang masih terbatas pada tataran kemampuan operasional konkret. Dengan demikian diharapkan melalui penerapan model pendekatan kontekstual dengan memanfaatkan lingkungan sebagai media dan sumber belajar IPS, motivasi, aktivitas, kreativitas, dan gairah belajar siswa menjadi meningkat, dan 
pada akhirnya timbul sikap baru menyenagi pembelajaran IPS. Dengan demikian perlahan-lahan akan mampu menghapus image bahwa IPS merupakan mata pelajaran yang membosankan dan dianggap sebagai mata pelajaran kelas dua setelah Matematika dan IPA (Sains), dan yang terpenting bahwa pembelajaran IPS menjadi lebih bermakna bagi siswa dalam menjalani hidup di lingkungan masyarakatnya.

Dari beberapa penelitian yang pernah dilakukan para peneliti sebelumnya, menujukkan bahwa pembelajaran yang menggunakan lingkungan sebagai sumber belajar, dapat meningkatkan kualitas pembelajaran dan hasil belajar menjadi lebih bermakna. Seperti hasil penelitian Istianti (2004:167) menyimpulkan bahwa pemanfaatan lingkungan sekitar sebagai sumber belajar, efektif dalam memberikan kedalaman makna materi dan pengertian kepada siswa berkenaan dengan topik yang menjadi bahan pelajaran. Demikian pula salah satu kesimpulan hasil penelitian Sumaryana,I. (2002:122), antara lain menyatakan bahwa: "melalui pemanfaatan lingkungan sebagai sumber belajar, dapat meningkatkan kesadaran siswa terhadap kebersihan lingkungan sekolahnya”.

Tujuan pendidikan dasar pada umumnya, yakni menghasilkan lulusan yang beriman dan bertakwa kepada Tuhan Yang Maha Esa, berakhlak mulia mengembangkan potensi peserta didik agar menjadi anggota masyarakat yang bertanggung jawab dan demokratis. Namun mengingat keluasan dan kompleksitas tujuan pendidikan dasar tersebut, maka dalam penelitian ini akan dibatasi pada pemahaman konsep dan sikap kepedulian sosial siswa kelas tiga Sekolah Dasar terhadap lingkungannya. Hal ini didasari atas pertimbangan bahwa siswa kelas tiga SD berada pada fase perkembangan kognitif operasional konkret yang kemampuan pemahamannya masih terbatas pada konsep-konsep factual sederhana, dan siswa kelas tiga SD telah mengalami hidup dalam ketiga lingkungan pembelajaran, yakni lingkungan keluarga, sekolah, dan masyarakat. Karena itu pula penelitian ini akan lebih memfokuskan pada penerapan model pendekatan pembelajaran pemanfaatan lingkungan sebagai sumber belajar IPS pengaruhnya terhadap peningkatan pemahaman konsep dan pengembangan sikap kepedulian sosial siswa Sekolah Dasar. Dengan harapan, melalui pemanfaatan lingkungan sebagai sumber belajar IPS mampu memenuhi tuntutan kebutuhan belajar dan tuntutan perkembangan siswa, 
sehingga pembelajaran IPS menjadi lebih bermakna (meaningful learning) bagi keseharian hidup siswa dalam lingkungan masyarakatnya.

\section{B. METODOLOGI PENELITIAN}

Penelitian ini menerapkan metode eksperimen kuasi, (Arikunto,2006) dengan desain kelompok acak pretest dan posttest dengan kelompok kontrol (Control Group Pretest-Posttest Design).

Lokasi yang dijadikan obyek untuk kepentingan penelitian ini adalah SD Sukahaji 1 dan 2 Cimekar Kecamatan Cileunyi, dengan subyek sampel penelitian seluruh siswa kelas tiga dari kedua SD tersebut pada semester dua tahun pelajaran 2008/2009, yang ditetapkan dalam dua kelompok acak yaitu masing-masing 50 siswa pada kelompok eksperimen dan 50 siswa dalam kelompok kontrol.

Alat pengumpul data untuk kepentingan penelitian ini terdiri atas: (1) alat tes pemahaman konsep berbentuk soal pilihan ganda, (2) Angket sikap kepedulian sosial siswa dengan Skala Likert, (3) lembar LKS pengamatan kelompok, dan (4) pedoman observasi implementasi perilaku kepedulian sosial siswa selama mengikuti proses pembelajaran.

\section{HASIL PENELITIAN DAN PEMBAHASAN}

\section{Analisis Data Penelitian}

a. Pengaruh Pemanfaatan Lingkungan Sebagai Sumber Belajar IPS Terhadap Peningkatan Pemahaman Konsep

Dari hasil pengolahan data diperoleh besaran persentase pemahaman konsep yang digambarkan melalui tabel perbandingan antara skor pretest dan posttest pada kelompok eksperimen sebagai berikut:

Tabel 1. Deskripsi skor Pretest dan Postest Pemahaman Konsep pada Kelompok Eksperimen

\begin{tabular}{|c|c|c|c|c|c|}
\hline \multirow{2}{*}{ No } & \multirow{2}{*}{ Kategori } & \multicolumn{2}{|c|}{ Pretest } & \multicolumn{2}{c|}{ Postest } \\
\cline { 3 - 6 } & & $\mathbf{f}$ & $\%$ & f & \% \\
\hline 1 & Rendah & 21 & 42.00 & 2 & 4.00 \\
\hline
\end{tabular}




\begin{tabular}{|c|c|c|c|c|c|}
2 & Sedang & 14 & 28.00 & 1 & 2.00 \\
\hline 3 & Tinggi & 15 & 30.00 & 47 & 94.00 \\
\hline \multicolumn{2}{|c|}{ Total } & $\mathbf{5 0}$ & $\mathbf{1 0 0}$ & $\mathbf{5 0}$ & $\mathbf{1 0 0}$ \\
\hline
\end{tabular}

Sumber: data yang sudah diolah

Data hasil penelitian pada tabel di atas, menunjukkan bahwa penerapan model pendekatan pemanfaatan lingkungan sebagai sumber belajar IPS, ternyata mampu meningkatkan pemahaman konsep siswa kelas tiga Sekolah Dasar secara signifikan dan berpengaruh positif terhadap peningkatan pemahaman konsep siswa terhadap lingkungannya. Dari hasil analisis data yang berhubungan dengan pemahaman konsep yang diawali dengan pelaksanaan tes awal (pretest) untuk mengetahui pengetahuan dasar siswa (entry behavior). Berdasarkan hasil uji komparatif (uji-t), ternyata menunjukkan peningkatan pemahaman konsep yang berarti (signifikan). Hal itu terbukti bahwa siswa yang memperoleh skor pretest pada kategori tinggi hanya diperoleh sebagian kecil siswa (30,00\%). Kemudian setelah memperoleh perlakuan dan diakhiri dengan kegiatan tes akhir (posttest), ternyata kelompok siswa yang memperoleh skor pada kategori tinggi dicapai oleh hampir seluruh siswa $(94,00 \%)$.

Besarnya pengaruh pemanfaatan lingkungan sebagai sumber belajar IPS bagi pemahaman konsep siswa terhadap lingkungannya, terlihat dari peningkatan hasil belajar yang termasuk kategori tinggi, mencapai 64,00\%. Berdasarkan analisis data melalui pengujian komparatif terhadap peningkatan yang terjadi pada skor hasil posttest kelas eksperimen melalui uji-t (T-tes), dapat disimpulkan bahwa peningkatan yang terjadi antara skor hasil pretest dengan skor hasil posttest pada kelompok eksperimen terdapat perbedaan yang signifikan.

Untuk memperkuat penyimpulan pada akhir pembahasan tentang besarnya pengaruh pemanfaatan lingkungan sebagai sumber belajar IPS, dapat ditunjukkan melalui data-data pada tabel 2 tentang deskripsi skor posttest pemahaman konsep pada kelompok kontrol dan kelompok eksperimen sebagai berikut: 
Tabel 2. Deskripsi skor Posttest Pemahaman Konsep pada Kelompok Kontrol dan Kelompok Eksperimen

\begin{tabular}{|c|c|c|c|c|c|}
\hline \multirow{3}{*}{ No } & \multirow{3}{*}{ Kategori } & \multicolumn{4}{|c|}{ Postest } \\
\hline & & \multicolumn{2}{|c|}{ Kontrol } & \multicolumn{2}{|c|}{ Eksperimen } \\
\hline & & $\mathbf{f}$ & $\%$ & f & $\%$ \\
\hline 1 & Rendah & 7 & 12.00 & 2 & 4.00 \\
\hline 2 & Sedang & 31 & 62.00 & 1 & 2.00 \\
\hline 3 & Tinggi & 7 & 14.00 & 47 & 94.00 \\
\hline \multicolumn{2}{|c|}{ Total } & 50 & 100 & 50 & 100 \\
\hline
\end{tabular}

Sumber : data yang sudah diolah

Dari data yang ditunjukkan pada tebel 2 di atas, memberikan gambaran yang lebih jelas tentang besaran persentase perolehan skor posttest pemahaman konsep antara kelompok kontrol dengan kelompok eksperimen. Data tersebut mengisyaratkan bahwa perolehan skor posttest kelompok kontrol yang termasuk katedori tinggi hanya diraih oleh sangat sedikit siswa $(14,00 \%)$, sedangkan skor posttest yang diperoleh kelompok siswa yang tergolong kategori tinggi pada kelompok eksperimen diraih oleh hampir seluruh siswa (94,00\%). Dengan demikian peningkatan besaran persentase pemahaman konsep sebagai pengaruh pemanfaatan lingkungan sebagai sumber belajar IPS menunjukkan perbedaan peningkatan yang signifikan mencapai 80,00\%, dan berarti pula mengisyaratkan bahwa pemanfaatan lingkungan sebagai sumber belajar IPS berpengaruh positif bagi peningkatan pemahaman konsep siswa terhadap konsep-konsep lingkungan sekolahnya.

Dengan demikian jelaslah bahwa pemanfaatan lingkungan sebagai sumber belajar IPS berpengaruh positif bagi peningkatan pemahaman konsep siswa kelas tiga Sekolah Dasar Sukahaji terhadap lingkungannya. Peningkatan pemahaman konsep yang terjadi pada kelompok eksperimen merupakan bentuk konkret pemberian kontribusi dari model pembelajaran dengan membawa siswa langsung ke dalam lingkungan kehidupan nyata, sehingga melalui karyawisata dan pengamatan langsung, selain dapat menghilangkan verbalisme pemikiran siswa, juga dapat meningkatkan motivasi, aktivitas, kreativitas, dan gairah belajar siswa. Hal itu disebabkan karena model dan metode pembelajaran IPS yang diterapkan guru telah 
mampu menggali sejumlah potensi dasar yang dimiliki setiap siswa sesuai dengan fase perkembangan kognitif intelektual siswa. Karena itu pula situasi belajar disikapi siswa sebagai proses pembelajaran yang menyenangkan (enjoyful learning).

\section{b. Pengaruh Pemanfaatan Lingkungan sebagai sumber belajar IPS bagi pengembangan sikap kepedulian sosial siswa terhadap lingkungan}

Untuk mengetahui besaran pengaruh dari pemanfaatan lingkungan sebagai sumber belajar IPS terhadap pengembangan sikap keperdulian sosial siswa, diperoleh skor rata-rata sebelum memperoleh perlakuan pemanfaatan lingkungan sebagai sumber belajar IPS (pretest) dan setelah memperoleh perlakuan pemanfaatan lingkungan sebagai sumber belajar IPS pada kelompok eksperimen disajikan pada tabel 3 sebagai berikut:

Tabel 3. Statistik Pretest dan posttest Sikap Kepedulian Sosial

\begin{tabular}{|l|l|l|}
\hline \multirow{2}{*}{ Statistik } & \multicolumn{2}{c|}{ Sikap Kepedulian Sosial } \\
\cline { 2 - 3 } & \multicolumn{1}{|c|}{ Sebelum Proses } & \multicolumn{1}{c|}{ Setelah Proses } \\
\hline Rata-rata & 114.34 & 135.18 \\
\hline Simpangan baku & 7.198667677 & 5.906378427 \\
\hline $\mathrm{N}$ & 50 & 50 \\
\hline
\end{tabular}

Sumber : data yang sudah diolah

Data berkenaan dengan sikap kepedulian sosial siswa terhadap lingkungannya, dihimpun melalui instrument angket pernyataan sikap siswa menurut skala Likert, dan setelah seluruh data terhimpun, kemudian diolah melalui uji-t dengan maksud untuk mengetahui apakah ada perbedaan sikap kepedulian sosial siswa antara sebelum memperoleh perlakuan pemanfaatan lingkungan sebagai sumber belajar IPS dengan setelah memperoleh perlakuanyang sama.

Berdasarkan perhitungan pada tabel.3 di atas, dapat diketahui skor rata-rata sebelum mendapat perlakuan pemanfaatan lingkungan sebagai sumber belajar IPS adalah 114,34, sedangkan setelah mendapat perlakuan pembelajaran dengan memanfaatan lingkungan sebagai sumber belajar IPS sebesar 135,18. Kemudian simpangan baku sebelum mendapat perlakuan pemanfaatan lingkungan sebagai 
sumber belajar IPS adalah 7.198667677, sedangkan simpangan baku untuk kelompok siswa setelah mendapat perlakuan pemanfaatan lingkungan sebagai sumber belajar IPS sebesar 5.906378427.

Dengan demikian menunjukkan bahwa pemanfaatan lingkungan sebagai sumber belajar IPS berpengaruh positif terhadap pengembangan sikap kepedulian sosial siswa kelas tiga Sekolah Dasar Sukahaji Cimekar Kecamatan Cileunyi, meskipun besaran peningkatannya tidak terlalu tinggi terhadap pengembangan sikap sosial siswa. Namun yang cukup menggembirakan dari hasil observasi terhadap implementasi perlakuan sikap yang dinyatakan melalui pernyataan angket, ternyata menunjukkan konsistensi perilaku sikap antara yang dinyatakan dalam angket dengan implementasinya di lapangan. Dengan demikian dapat disimpulkan bahwa pemanfaatan lingkungan sebagai sumber belajar IPS, berpengaruh posistif bagi pengembangan sikap kepedulian sosial siswa terhadap lingkungannya. Pengembangan sikap tersebut dengan sedirinya berhubungan erat dengan suara hati yang kadar kepeduliannya relatif berbeda. Hal ini sejalan dengan tahapan perkembangan menurut Havighurst, bahwa "pada aspek perkembangan suara hati anak usia tersebut seharusnya anak belajar banyak peraturan dan pengembangan kebenaran moralitas”. Peraturan dan perkembangan kebenaran moralitas akan menjadi milik seorang invidu apabila selalu dilakukan melalui pembiasaan dan belajar pengulangan. Hal itu sejalan dengan pendapat senada antara Vygosky dan Yudha,A. Vygotsky antara lain menegaskan bahwa "Pengulangan dan latihan hendaknya secara terus menerus dilakukan dan digunakan, sehingga perilaku yang diinginkan dapat menjadi kebiasaan”. Sedangkan menurut Yudha (2009), bahwa "Belajar pengulangan berfungsi memelihara pengetahuan dan keterampilan yang dimiliki seseorang, karena kebanyakan yang dipelajari manusia membutuhkan pengulangan untuk memperkokoh kebiasaan positif”.

\section{KESIMPULAN}

1. Hasil penelitian ini memberikan gambaran bahwa penerapan model pendekatan pemanfaatan lingkungan sebagai sumber belajar IPS memberikan pengaruh positif dalam meningkatkan pemahaman konsep siswa kelas tiga Sekolah Dasar 
terhadap lingkungannya. Hal ini merupakan salah satu bukti konkret implementasi teori perkembangan kognitif Piaget, yang menyatakan bahwa: "Perkembangan anak usia sekolah (7-12) tahun berada pada fase perkembangan kognitif operasional konkret (concrete operations), yang ditandai dengan kemampuan mengelompokkan (mengklasifikasi), menyusun atau mengasosiasikan (menghubungkan atau menghitung) angka atau bilangan, dan sikap memecahkan masalah (problem solving) yang sederhana”.

Pengenalan konsep-konsep lingkungan oleh guru pada saat pembelajaran, secara kelompok siswa dihadapkan langsug dengan berbagai konsep yang terdapat pada masing-masing obyek amatan kelompok, dengan tuntutan siswa mampu mengelompokkan konsep-konsep yang sejenis untuk kemudian dianalisis secara sederhana sesuai dengan kemampuan berbahasa siswa kelas tiga SD. Dengan demikian, agar proses pembelajaran IPS lebih bermakna, maka pemanfaatan lingkungan sebagai sumber belajar dapat dijadikan sebagai salah satu alterntif pilihan guru dalam memperkaya hasanah pembelajaran IPS..

2. Selain berpengaruh terhadap peningkatan pemahaman konsep, penelitian ini berimplikasi pula terhadap pengembangan sikap kepedulian sosial siswa, karena konsep-konsep yang dikembangkan guru diterapkan melalui pengamatan dan pengalaman langsung dalam lingkungan kehidupan yang factual, sehingga melalui belajar dari pengalaman yang menyenangkan akan menjadi proses belajar pengulangan yang selanjutnya akan menjadi proses pembiasaan yang posiif. Dalam hal pembiasaan sikap positif yang terbentuk dari pemahaman sejumlah konsep, bahwa hasil belajar pengulangan apabila dilakukan secara terus menerus akan menjadi kebiasaan dan dapat berfungsi untuk memelihara pengetahuan dan keterampilan yang dimiliki oleh seseorang. Dengan demikian apabila guru akan menerapkan model pendekatan pemanfaatan lingkungan sebagai sumber belajar untuk tujuan membentuk dan mengembangkan sikap kepedulian sosial siswa, maka guru hendaknya terampil memilih lingkungan yang relevan dan menyenangkan, menerapkan belajar pengulangan, dan menerapkan pembiasaan sikap positif melalui keteladanan guru. 


\section{DAFTAR PUSTAKA}

Akdon. (2008). Aplikasi Statistika dan Metode Penelitian untuk Administrasi dan Manajemen. Bandung: Dewa Ruchi.

Al Muchtar, S. (2004). Pengembangan Berfikir dan Nilai Dalam Pendidikan IPS, Bandung: Gelar Pustaka Mandiri.

Arends, R.I. (1989). Learning To Teach, International Edition, Singapore: MC. Graw-Hil Book.

Arikunto, S.(2006). Prosedur Penelitian Suatu Pendekatan Praktik. Jakarta: Rineka Cipata.

AsepYudha.(2009).PembelajaranAnak.http://asepyudha.staff.uns.ac.id/2009/05/30/p embelajaran-anak/

Banks, A.James. (1990). Teaching Strategies For The Social Studies. New York \& London: Jr. Longman Inc.

Depdiknas RI. (2006). Peraturan Mendiknas Nomor 22 Tahun 2006 Tentang Standar Isi. Jakarta: Depdiknas.

Hasan, Said, H. (2004). Kurikulum dan Tujuan Pendidikan, Jurnal JPIS. Bandung: Media Komunikasi Antar FPIPS-UPI, FKIP Universitas/STKIP SeIndonesia.

Hernawan, I. (2004). Pendidikan Nilai Lokal Sebagai Upaya Membentuk Generasi Muda Yang Bermoral. Jurnal Pendidikan Ilmu Sosia (JPIS)Nomor 23, Halaman 42 Bandung: Media Komunikasi Antar FPIPS-UPI, FKIP Universitas/STKIP Se-Indonesia, Halaman .

Hurloock, B. Elizabeth. (1980). Developmental Psykology A Life Approach, Edisi Terjemahan. Jakarta: Erlangga.

Istianti, T. (2004), Peningkatan Pembelajaran Pendidikan Ilmu Pengetahuan Sosial di SD Melalui Pemanfaatan Lingkungan Sekitar Sebagai Sumber Belajar, Bandung: UPI, Tesis.

Ningrum, E. (2004). Kompetensi Guru Mendayagunakan Lingkungan dalam Pembelajaran IPS. Bandung: Jurnal Pendidikan Ilmu Sosial (JPIS), No.23 Halaman 35, Media Komunikasi Antar FPIPS-UPI, FKIP Universitas/STKIP Se- Indonesia.

Pasya, G.K. (2000). Lingkungan Sebagai Sumber Belajar. (2000), Jurnal Pendidikan Ilmu Sosial (JPIS) No. 16 Halaman 28, Media Komunikasi Antar FPIPSUPI, FKIP Universitas/STKIP se-Indonesia.

Poedjiadi, Anna. (2005). Sains Teknologi Masyarakat, Model Pembelajaran Kontekstual Bermuatan Nilai, Bandung: Remaja Rosdakarya.

Sapriya, dkk. (2007). Pengembangan Pendidikan Ilmu Pengetahuan Sosial. Bandung: UPI Press.

-, (2008). Pendidikan Ilmu Pengetahuan Sosial. Bandung: Laboratorium PKn UPI.

, (2008). Pendidikan Ilmu Pengetahan Sosial di SD. Bandung: UPI Press. , (2007). Konsep Dasar Ilmu Pengetahuan Sosial. Bandung: Laboratorium PKn UPI. 
Sayakti, L. (2003). Implementasi Konsep Lingkungan Hidup Sebagai Sumber Belajar Dalam Pembelajaran IPS di SD, UPI Bandung: Tesis Tidak dipublikasikan.

Somantri, M.Numan. (2001). Menggagas Pembaharuan Pendidikan IPS. Bandung: Remaja Rosdakarya Offset.

Sumaatmadja, N. (1998). Manusia dalam Konteks Sosial, Budaya, dan Lingkungan Hidup. Bandung: Alumni. , (1997). Konsep Dasar Ilmu Pengetahuan Sosial. Jakarta: DepdikbudUniversitas Terbuka.

-, (1986). Pengantar Studi Sosial. Bandung: Alumni.

, (1986). Perspektif Studi Sosial. Bandung: Alumni

, (2002).Pendidikan Pemanusiaan Manusia Manusiawi,. Bandung: Alfabeta.

Winataputra, Udin.S. (2002). Materi dan Pembelajaran IPS di SD. Jakarta: Pusat Penerbitan Universitas Terbuka.

------------, (1977). Buku Materi Pokok Strategi Belajar Mengajar. Jakarta: Depdikbud Universitas Terbuka.

Witherington,H. C. (1982). Teknik-Teknik Belajar dan Mengajar. Bandung: Jemmarars.

\section{BIODATA}

Uus Yusmantara S. adalah dosen pada UPBJJ Universitas Terbuka Bandung. Menyelesaikan pendidikan jenjang magister dari Sekolah Pascasarjana UPI Bandung. 